\title{
THE IMPACT OF THE D21 METHOD AND ITS MODIFICATION ON CITIZENS' PARTICIPATION IN PARTICIPATORY BUDGETING. THE CASE OF THE CZECH REPUBLIC
}

\author{
Soňa Kukučková ${ }^{1}$, Marie Poláchová ${ }^{2}$
}

\begin{abstract}
Participatory budgeting $(P B)$ is often discussed as a tool to support active participation of citizens in the decision-making in the matters of the distribution of public resources. However, little was said about the possibility that the choice of a voting method used in the voting phase of the PB process could affect the participation in PB. In the Czech Republic, the Democracy 2.1 (D21) voting method is often used in municipalities implementing $P B$ and additionally, it is promoted as a method to encourage more people to vote. This article aims to determine Czech municipalities with the D21 method and its modification, and to evaluate the impact of choosing these voting methods on participation rate in PB. The study suggests that the choice of a voting method is relevant for citizens' engagement in voting. Based on the empirical findings, the D21 method and its modification are associated with a higher voter turnout in $P B$ than another voting method. Further, the results underline the influence of external organizations offering online platforms for voting.
\end{abstract}

KEY WORDS: Participatory budgeting, Voting method, Voter turnout, Arrows impossibility Theorem, D21 Method.

\section{INTRODUCTION}

Currently, participatory budgeting enables citizens to deliberate and negotiate over the distribution of public resources (Wampler, 2012). After the first PB applied in Porto Alegre in 1989 made participatory budgeting more popular, various examples can be found globally. Other new cases soon emerged in South and North America following the promotion of PB by the United Nations (Shah, 2007). European examples of PB increased from 55 in 2005 to almost 2,700 in 2021 (Officina, 2021).

\footnotetext{
${ }^{1}$ Faculty of Business and Economics, Mendel University in Brno, Zemědělská 1665/1, 61300 Brno, Czech Republic, E-mail: sona.kukuckova@mendelu.cz, ORCID: 0000-0002-1740-0663. ${ }^{2}$ Faculty of Business and Economics, Mendel University in Brno, Zemědělská 1665/1, 61300 Brno, Czech Republic, E-mail:marie.polachova@mendelu.cz, ORCID: 0000-0002-9014-5961.
} 
Different types of PB have been developed during its widespread implementation based on country-specific conditions and factors. The PB classification is available in Sintomer et al. (2008) or later in Miller et al. (2019). Wampler in Shah (2007) differentiates between two types of participatory budgeting programs: project - focused PB (public works programs) and PB focused on thematic programs (general spending policies). Project-oriented PBs could often be found in EU countries, mainly in CEE countries (Džinić et al., 2016; Olejniczak, Bednarska-Olejniczak, 2018; Kukučková, Bakoš, 2019) and these PBs prevail also in Canada and in the U.S. (Calabrese et al., 2020; Carrol et al., 2016; Lerner, Secondo, 2012; Pape, Lerner, 2016).

The common PB procedure of a project-oriented PB follows a few basic rules. First, a municipality allocates a certain amount of the local budget; mostly this amount is considerably lower than a municipal budget itself. Then a municipality launches the time-limited competition for submission of individual proposals. This enables the citizens to be part of the decisionmaking about public resources and may be considered one of the approaches of promoting the participatory democracy (European Parliament, 2016).

The number of participants in participatory budgeting does not often fulfil the expectations of politics and public administration (Zepic et al., 2017). Only few PB participants can lead to PB being perceived as a process with low legitimacy because citizen interests lack their representativeness when only a few citizens participate (Kukučková, Bakoš, 2019; Zepic et al., 2017; Wampler, 2012; Bhatnagar et al., 2003). A low participation rate was often described as a problem in the CEE countries (see, e.g., Džinić et al., 2016; Fölscher, 2007). In the Czech Republic, the participation rate in PB is approximately 6\% on average from 2014 to 2019 (Sedmihradská, Kukučková, Bakoš, 2022) ranging from 0.5 to $15.9 \%$ of eligible voters in 2019 (Minárik, 2020), which could be perceived by politicians or citizens as insufficient. Municipalities choose different PB rules including voting methods and rules on participation in the voting process. The selection of suitable voting conditions and methods could increase voter turnout in PB.

The article analyses application of the Democracy 2.1 (D21) method and other voting methods in the Czech Republic as used in PB. The D21 method was proposed by Karel Janeček and enables voters to use more positive votes and minus vote(s) when certain conditions are met (Janeček in Sedmihradská, Kukučková, Bakoš, 2022). Janeček (2016) states that "voters may cast up to four plus-votes and up to two minus-votes." We describe the exact definition criteria of the D21 method in the section Data and methods. 
The D21 method is promoted as the way of obtaining more information from a voter. The benefits related to the effect of more votes are that a voter gives more information in a single ballot than in a situation that has only one preferred candidate to select. Therefore, the method should have greater impact to well-informed and engaged voters by applying systematically capped multiple votes (Janeček, 2016, www.ih21.org).

Since 2015, a voting online platform using the D21 method has been used in more Czech municipalities and in 11 other states, e.g., in the U.S. (New York), Tunisia, Zambia, France (www.ih21.org). Based on the assumption that the attractiveness of D21 method could enhance voters' engagement in voting, this hypothesis was formulated:

H1: Municipalities using the D21 voting method have a higher participation rate in voting on $P B$ projects than the municipalities using the voting method not in line with the D21 voting method's definition.

This article aims at identifying the Czech municipalities applying the D21 method and its modification, and at evaluating the impact of choosing this voting method on participation rate in PB. In order to provide balanced information, the authors outline potential limits of this method in general and in specific PB cases in different municipalities, and analyse the cases when the method was changed. Empirical part focuses on the situation in 2019 before the COVID-19 pandemics. Assumption here is that there might be a high impact of COVID-19 on the participation rate in most of the municipalities and the aim is to mitigate this influence. This assumption is based on the preliminary data for the Czech Republic in 2020 and a similar conclusion of the analysis performed by Bardovič and Gašparík (2021) in Slovakia. The results may help to understand the potential of the research problem for further investigating.

The article is structured as follows. First, a brief review of PB in the Czech Republic is presented with the focus on the voting process and methods for voting on PB projects. Second, theoretical background concerning different voting methods applicable in PB is outlined with the focus on the D21 method. Third, the structure of the dataset and used methods are described. In the next section, the classification of municipalities based on the applied voting method and the evaluation of the participation rate in PB in different classification groups are presented. The main results are then discussed, and possible implications are outlined. 


\section{PARTICIPATORY BUDGETING IN THE CZECH REPUBLIC AND THE PB VOTING PROCESS}

The first municipal participatory budget was introduced in the city district of Prague 7 in 2014. The pilot project was not very successful and ended after one year. In the same year, the Czech Pirate Party established its own project fund based on similar principles as participatory budgeting (Czech Pirate Party, 2020). In 2015, other organizations started promoting participatory budgeting, as Agora Central Europe (Agora CE, 2015) and Participation 2.1 (now Institute H21) using the D21 method for voting in most cases. Since 2016, the concept of the Healthy Cities has also supported the PB introduction in the context of Local Agenda 21 (Sedmihradská, Kukučková, Bakoš, 2022).

According to the definition of territorial statistics used by Eurostat, the Czech local government includes 6258 municipalities, representing local administration units 2 (LAU2), in 2021 (CSO, 2021). Therefore, the Czech Republic is one of the most fragmented countries in Europe and $80 \%$ of Czech municipalities have less than 2000 inhabitants. The number of Czech municipalities with PB ("PB municipalities") is not so high (61 cases in the analysis of the year 2020), but larger cities implement PB more often. Therefore, the total population potentially involved in the PB process is relatively high (approximately $20 \%$ of the Czech population in 2020).

Graph 1: Spread of participatory budgeting in the Czech Republic in 20142020

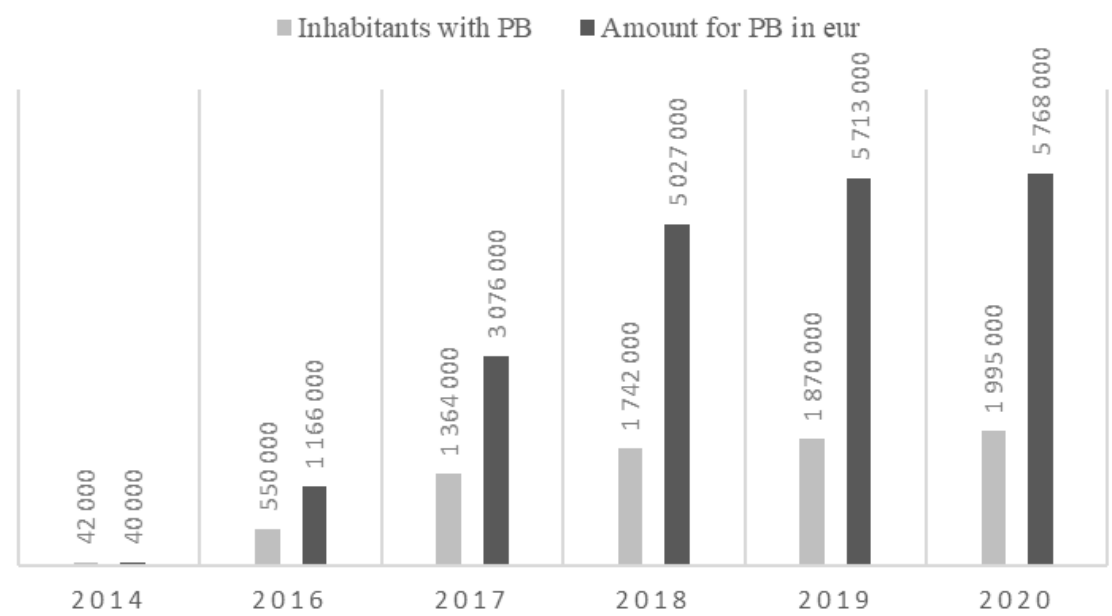

Source: The authors 
The number of inhabitants who have the possibility to participate in PB increased from 42 thousand in 2014 to almost 2 million in 2020. The amount allocated for PB projects reached approximately 6 million euro in 2020 (see Graph 1). In the empirical part, the focus is on the year 2019 to eliminate the influence of COVID-19 on the participation rate in PB. Therefore, the voting process in PB in 2019 is described then in detail, which enables to outline the framework for this analysis.

The general election rules for the municipal election required a strict minimum voting age of 18 years and permanent residence in the municipality. In municipalities in the Czech Republic, the rules for voting on PB projects are more open. A lower voting age is often accepted - usually the age of 15 or 16 (44\% of the PB municipalities in 2019) which confirms that the PB was indeed used to encourage young citizens to participate. Other frequently used criteria for voting are a permanent address in the municipality (63\% of the PB municipalities in 2019) and even an address in an individual district to vote for a project located in that district of a municipality. In some municipalities, there are exceptions for citizens without permanent residence in case they can prove a reasonable connection to a municipality, for instance, by owning a real estate, studying, working, or spending free time in the municipality.

Almost all communities used online and digital tools to vote on PB projects. There were only five municipalities without online voting on $\mathrm{PB}$ projects in 2019. Ninety-one per cent of the PB municipalities require online voting. In $37 \%$ of municipalities, there was possibility to vote in person in year 2019 (Sedmihradská, Kukučková, Bakoš, 2022). Combination of digital and ballot - paper voting through machine recognition of results was also present. In the case of online voting, a proper online voting platform was necessary (Černý, 2016).

The choice of a voting rule for PB depends on financial, personal resources, and IT tools of the given municipality. Smaller municipalities often choose the cheapest and the simplest solution without further investment into websites or IT tools for projects' presentation or voting. Larger towns implementing PB often outsource a part of the PB process to external firms and pay for advisory services or a web platform maintenance. Czech municipalities often use services of external providers and organizations for voting on the PB projects - 57\% of the PB municipalities in 2019 (Sedmihradská, Kukučková, Bakoš, 2022) and 58\% in 2020. Details for 2020 are presented in Graph 2. 
Graph 2: Municipalities with outsourcing of voting systems/tools in Czech PBs in 2020 (Number of municipalities)

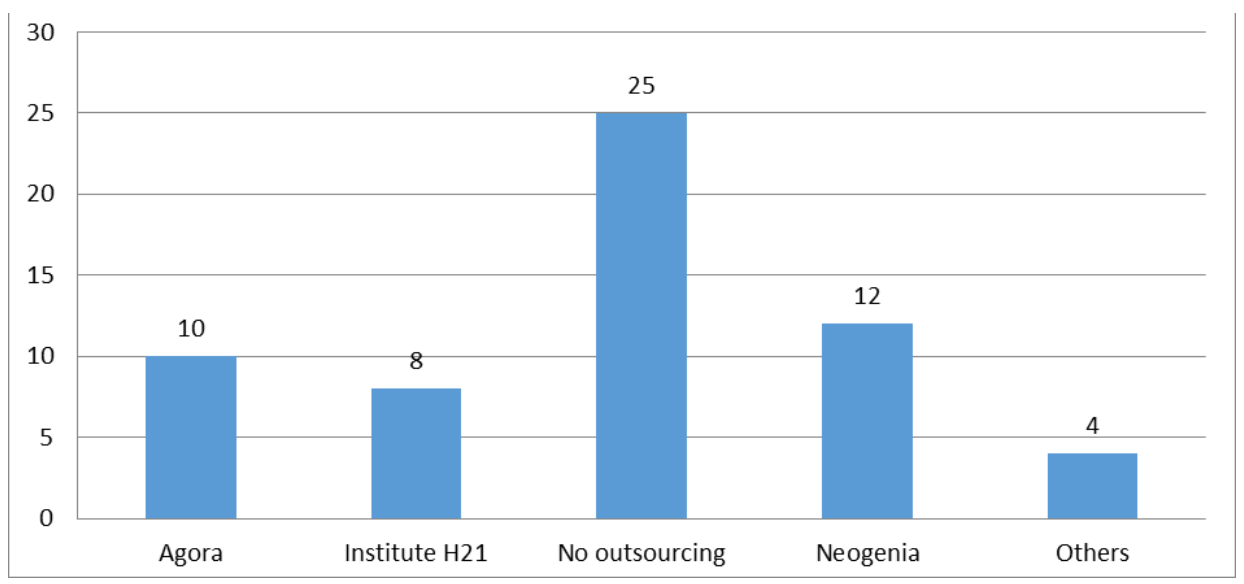

Source: The authors

As already mentioned, Agora Central Europe and Participation 2.1/ Institute $\mathrm{H} 21$ played an important role in the pilot projects of PBs promoting their own services in this area. Agora often provides advisory and consulting services about the PB process and its rules, including the voting phase, and the services of the Institute $\mathrm{H} 21$ are more concentrated on voting and presentation of PB proposals. A relatively new organization in this area is Neogenia (Mobilní rozhlas) that offers online tools for civic participation and voting/surveys (Graph 2). During 2020, Neogenia enabled municipalities to use its applications for free, and this approach will increase its relevancy among other providers of voting platforms in the future. Mainly, small municipalities use their own survey tools for voting purposes.

The Institute H21 offers voting systems applying the D21 method and Agora recommends voting methods based on similar principles. Therefore, it could be assumed that the D21 and the modified D21 voting method are frequently used in Czech municipalities to vote on PB proposals. Other voting methods identified during data analysis were plurality with one positive vote per voter or the method with more positive votes without the possibility of casting the minus vote(s). 


\section{CHOICE OF A VOTING METHOD FOR PB AND THE D21 METHOD}

In this section, conditions for ideal voting rules are briefly presented and discussed. In the Czech Republic, the plurality method and the method with more positive votes per voter are used for PB, therefore these methods are analysed here in detail. Later, possible alternative methods are outlined, which can be used in PB based on the use of more votes or offer an opportunity to score/rank more alternatives. In the end of the section, the article focuses on the D21 method and its possible drawbacks concerning ideal rules.

The experts' opinions on the choice of an appropriate rule for voting are not unanimous. In simple terms, the Arrows' Impossibility Theorem considers voting fundamentally unfair - social choice criteria as ideal conditions are not met in any case of democratic voting methods with at least three distinct alternatives (Arrow, 1951; Arrow, 1977; Arrow, Maskin, 2012). On the contrary, empirical evidence is obviously not as sceptical as the theoretical literature (Regenwetter, 2006; Regenwetter et al., 2009).

These conditions, enabling converting the individual preferences into a community choice, are following: universal domain, non-dictatorship, non-imposition, independence of irrelevant alternatives, positive association, completeness, and transitivity (Tabarrok, 2015). Concisely, different voting methods violate at least one of the conditions of the Arrow's Theorem under the assumptions defined above. However, there are additional criteria proposed by other authors such as the Condorcet winner (CW) or the Condorcet looser (CL) criterion. A Condorcet winner is a candidate/an option, which wins a simple majority against each of the others when every pair of candidates is compared (McLean, McMillan, 2009). The CW criterion demands that if there is a Condorcet winner, in each case the voting rule must choose that alternative (Young, 1988). The Condorcet Looser criterion means that a candidate, who loses every pairwise comparison, never wins. Grofman and Feld (2004) consider four factors relevant to the choice of a voting rule: avoidance of Condorcet losers, choice of Condorcet winners, resistance to manipulability via strategic voting, and simplicity.

The first two conditions (universal domain and non-dictatorship) are fulfilled by most of the democratic voting methods. A universal domain means that all rational preferences of individuals could be inputs into the voting system. A non-dictatorship does not allow the rule to be based on solely one person's preferences. Non-Imposition is described by Arrow 
(1977, p. 617): "For every pair of alternatives, $x$ and $y$, there is some set of individual preferences such that $\mathrm{x}$ will be chosen over $\mathrm{y}$ and some set of preferences for which y will be chosen over x."

From other conditions, the focus will be on the independence of irrelevant alternatives and the positive association as one of the most problematic criteria. The independency of irrelevant alternatives describes Tabarrok (2015) as the situation where "the social ranking of $X$ and $Y$ should depend only on how individuals rank $\mathrm{X}$ and $\mathrm{Y}$ (and not on how they rank some 'irrelevant' alternative $\mathrm{W}$ relative to $\mathrm{X}$ and $\mathrm{Y}$ )." In simple words, when there is the third additional alternative to $\mathrm{X}$ and $\mathrm{Y}$, it cannot change the result of the decision.

A voting rule complies with the condition of positive association, if one alternative rises or remains still in the ordering without any other change in those orderings, it is expected that it rises, or at least does not fall in the social ordering (Arrow, 1951 in Mbih et al., 2010). In other words, if the voting rule outputs $X>Y$, then it should continue to output $X>Y$, when some individuals raise $X$ in their preference orderings (Tabarrok, 2015).

Globally, in PB many municipalities used the plurality-voting rule. During the preliminary data analysis in the Czech Republic, the plurality rule with one positive vote per voter is identified altogether with the method with more positive votes per voter.

The basic principle of the plurality method is that a voter casts a ballot for one candidate, and the candidate with the most votes (a majority or plurality) wins. The May's theorem demonstrates that, in social decisions with two options, the simple majority rule uniquely complies with the desired conditions (Goodin, List, 2006). However, two options are only exceptional in PB. The plurality rule used for decisions taken between more options is often criticized due to the revelation of only first choices and the provision of insufficient information via a balloting procedure (Wodak, 2019). GreenArmytage et al. (2016) consider the plurality rule as an ineffective in the sense of maximizing summed utilities. When the plurality method is used, a "Condorcet loser" can win by the obtaining of the most votes in the first place, but simultaneously of the most votes in the last place. Therefore, the result of that choice would not reflect the preferences of all voters on average and would conflict with the CW criterion. Some problematic aspects of the plurality-voting rule could be eliminated by the possibility to use multiple votes during election. The possibility of the casting of more votes motivates the voters to consider their choices and to better explain their preferences. More voting options could increase a voter turnout (Haman, Školník, 2020). 
However, using of more votes may result in violation of above-described conditions for voting methods based on the Arrow Theorem.

This section briefly presents some voting methods enabling the casting of more votes or score/rank more alternatives which can be used in voting for the $\mathrm{PB}$ projects and their possible drawbacks. Arguments for more votes are often used for the promotion of the approval voting (AV) method (Brams, Fishburn, 1978; 2007), which is possible to choose for voting on the PB projects. Each voter submits a separate ballot paper for each option, marking approval or disapproval of that option (Goodin, List, 2006). AV is as simple as the plurality rule and less burdensome and costly than runoff voting (Laslier, Sanver, 2010). The problem of AV might be the need for differentiation between good and bad options/candidates, thus the impossibility of expressing the intensity of the preferences (Ochrana, 2003). When voting on the PB project, this rule could result in a winner with the least opponents and not with the most sympathizers. Voters could vote strategically to weaken potential competitors of their preferred candidate, but it is less common than in the case of the plurality rule or range voting (Laslier, Sanver, 2010). AV tends to the choice of a 'merely inoffensive' option/ candidate and to avoid a strong candidate (Janeček, 2016). Additionally, the choice might by perceived by voters as more information demanding (Brams, Sanver, 2009) and could breach the condition of simplicity.

Poundstone (2008) promoted the range voting (RV), in which a voter scores each candidate on a numeric scale, the scores are added (or averaged), and the candidate with the highest average (or total) rating is a winner. This method enables a better expression of the preferences and their intensity for all candidates because a voter could evaluate every candidate. However, the score scale might be different with the possible impact on the result of the choice. Akin to AV, range voting rule could be for voters more complicated to make choice. Sometimes, they do not rank all candidates/options on a ballot, and their evaluation is incomplete. Additionally, the rule does not fulfil the principle of majority for all cases - a minority candidate may be elected against a majority candidate, the rule maximizes average evaluation only (Laslier, 2012).

The cumulative voting enables the casting of fixed number of points by each voter. Mostly, the term is commonly used in a corporate environment when electing company directors (e.g. Bhagat, Brickley, 1984). A shareholder has one vote per share multiplied by the number of directors to be elected (investopedia.org). In a simple form, it is used for voting on the PB projects, when a voter has the exact number of votes, and he/she can cast them 
to more projects. The number of votes could be limited or unlimited per a project. A project with the most votes wins. In contrast with the range voting, the cumulative voting requires an equal sum of all votes casted to the projects by each voter. However, both voting methods (range and cumulative voting) are under risk of dependency of irrelevant alternatives.

Wodak (2019) supported the preferential IRV (instant runoff) method based on the ranking of candidates and their gradual elimination. A voter rank candidate and his top preferences are counted. If a candidate obtains more than half of the votes, he or she wins. The candidate in the last place is eliminated from evaluation. Subsequently, the remaining top preferences are counted, and it is repeated until a candidate has the majority of votes for remaining candidates. A possible shortage of the method is a quite complicated counting procedure and, in the case of more rounds (runoff), it is time demanding. The rule also breaches the condition of positive association. Goodin and List (2006) drew attention to possible drawbacks of a voting rule with more votes - the fragmentation of votes among many candidates is accompanied by the loss of concentration on leading candidates and the information burden on voters. Additionally, voters can have incentives to vote strategically under the voting methods with more votes.

The theoretical presumption of the 21 method is a rational, well-informed voter. This voter is competent to make right decision in the voting process in line with his preferences (Janeček, 2016). However, there are other opinions on the rationality of a voter and his/her knowledge and understanding. The costs of acquiring information tend to be relatively high in some policy areas, and therefore many voters stay rationally ignorant (Congleton, 2001). Other factors influencing the decision-making of a voter/a citizen often mentioned in empirical studies of behavioural economists are, e.g., emotions (Ariely, 2010; Thaler, Sunstein, 2009), bias, framing (Kahneman, Tversky, 2000) or habits (Bechtel et al., 2018). Even the rain can impact the outcome of an election (Meier et al., 2019). Therefore, the reality might be different from the situation with the presence of a well-informed voter.

The casting of minus-votes enables voters to state their preferences more precisely by indicating the option they do not want to be chosen. Wodak (2019) stressed a morally significant difference between voting against via 'negative voting' (when one negative vote cancels out one positive vote) and expressing disapproval in the case of approval voting. Janeček (2016) points out that the plurality rule could result in the winning of a controversial candidate. The method D21 could eliminate this possibility by casting 
of negative votes to this candidate or by obtaining of less plus votes from him in total. In the case of PB, controversial projects could be identified by obtaining more negative votes and a municipality could pay attention to the possible problem in realization in advance. Nevertheless, the D21 has some drawbacks which need to be mentioned - the possibility of strategic voting, dependency of irrelevant alternatives, and complexity of the rule.

\section{DATA AND METHODS}

The dataset about participatory budgeting in the Czech Republic used in this research was compiled by means of desk-research, using data from the official websites of analysed municipalities and/or the websites on their participatory budgeting, complemented by information from minutes of municipal councils and local journals in the period 2014-2019. In the analysis of voting methods, the focus is on the year 2019 in the sample of 54 municipalities. The year of the participatory budget was assigned based on the year of voting on proposals because sometimes it started in the previous year. Therefore, other statistics about the number of PBs in the Czech Republic for a particular year may differ (e.g., from Agora or Institute H21). Data on numbers of potential voters in municipal elections are from the Czech Statistical Office (CSO).

First, municipalities are identified by the criteria to be met to indicate a voting method as the D21 method based on Janeček (2016):

1. more positive votes (P), the possibility to cast minus vote(s) (M),

2. "the number of plus votes has to be at least twice as large as the number of minus votes $\mathrm{P} \geq 2 \mathrm{M}$ " (Janeček, pp.9),

3. each voter can cast no more than one vote for any project,

4. positive votes $(\mathrm{P})$ are less than or equal to proposals for voting $(\mathrm{V}) \mathrm{P}$ $\leq \mathrm{V} / 2$,

5. "each vote has the same absolute weight $(+1$ or -1$)$. The winning candidates receiving the greatest sum of all votes win." (Janeček, pp.9).

The term modified D21 method is used if only the first condition is met and at least one of the other four is not fulfilled. Consequently, in this research the municipalities were divided into three groups - municipalities with the D21 method, municipalities with modified D21 method, and municipalities with another voting method. Additionally, the application of the D21 method was assumed when the Institute H21/Participation 21 organized voting 
through its online voting platform and concrete information on the number of votes was missing.

The first step was to evaluate the first criterion of the D21 voting method. Evaluation of criteria 2-5 was reasonable for municipalities that met the first criterion. Therefore, the number of the cases of PB tested for the criteria 2-5 is equal to the number of municipalities classified as municipalities with the D21 method or the modified D21 method.

Second, the participation rate in PB is calculated and compared in different groups of municipalities classified by voting methods. The participation rate in $\mathrm{PB}$ refers to the turnout in voting on $\mathrm{PB}$ projects and is measured as the number of $\mathrm{PB}$ voters on the number of all potential voters in the last municipal election (year 2018).

\section{FINDINGS AND DISCUSSION}

This section presents the frequency of the fulfilment of each criterion defined for the D21 voting method. Then, different groups of municipalities are identified as described in the Data and Methods section. Finally, descriptive statistics of voter turnout in PB are presented in the groups of municipalities using the D21 method (D21), its modification (Modified D21) and another voting method (Other). These groups are compared with the participation rate in $\mathrm{PB}$ in all municipalities.

Graph 3: Municipalities with $P B$ meeting the criterion 1: more positives votes $(P)$ and possibility to cast minus-vote(s) (M), N=54

Source: The authors

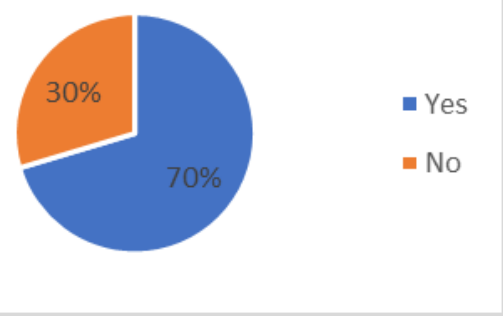

Seventy per cent of municipalities (38) enable the casting of more positive votes and there is also a possibility to use minus votes under certain conditions (Graph 3). In the next step, these municipalities were tested for 
other criteria (2-5) to be split into the groups of municipalities with the D21 method or with the modified D21 method. Municipalities using the D21 method must comply with all criteria.

Graph 4: Municipalities with $P B$ that meet criteria 2 and 3, $N=38$

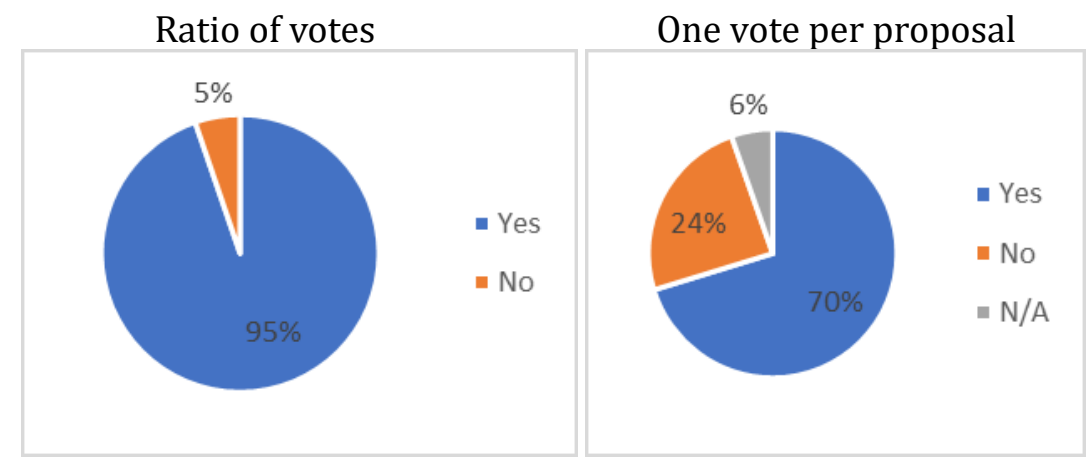

Source: The authors

Most of the municipalities that meet the first criterion have a ratio plus votes $(\mathrm{P})$ at least twice as large as the number of minus votes $(\mathrm{M})$, when $\mathrm{P}$ $<2 \mathrm{M}(95 \%)$. Seventy per cent of the municipalities enable the casting of only one vote per proposal, which is in line with the criterion 3 (Graph 4).

Graph 5: Municipalities with PB that meet criteria 4, $N=38$

Positive votes vs. proposals for voting

Source: The authors

Eighty-seven per cent of municipalities that met the first condition have the voting method with the number of positive votes $(\mathrm{P})$ that is less than 
or equal to the number of proposals for voting $(\mathrm{V})$ : $\mathrm{P} \leq \mathrm{V} / 2$ (Graph 5). The last criterion 5 is fulfilled by all municipalities, which met the first criterion except one municipality, municipality of Brno. During the PB process in 2019 , minus votes did not count towards the result in Brno. Negative votes are relevant only when proposals have the same number of positive votes to determine the order. In other cases, all votes (plus and minus) have the same absolute weight $(+1$ or -1$)$ and the proposal receiving the greatest sum of all votes wins. A summary of meeting the criteria for D21 method by Czech PB municipalities in absolute numbers is presented in Table 1.

Table 1: Number of PB municipalities meeting/failing the criteria for the D21 method in 2019, $N=54$

\begin{tabular}{|c|c|c|c|c|}
\hline Meeting the criteria & Yes & No & N/A & Total \\
\hline Criterion 1 & 38 & 16 & 0 & 54 \\
\hline Criterion 2 & 36 & 2 & 0 & 38 \\
\hline Criterion 3 & 26 & 9 & 3 & 38 \\
\hline Criterion 4 & 33 & 4 & 1 & 38 \\
\hline Criterion 5 & 37 & 1 & 0 & 38 \\
\hline
\end{tabular}

Source: The authors

The research identified 38 municipalities meeting the first criterion: 23 municipalities could be classified as a municipality with the D21 method (meeting all the criteria for the definition of D21 voting method) and 15 municipalities as a municipality with the modified D21 method.

In the next step, the impact of the use of the D21 voting method is evaluated concerning the voter turnout in $\mathrm{PB}$, which is measured as the number of $\mathrm{PB}$ voters (voters on PB proposals) over the number of all potential voters in the last municipal election (year 2018). The calculated rate is higher than reality because the PB voters could be aged under 18 in some municipalities (44\% municipalities have a lower voting age in 2019) but it provides sufficient information for evaluation purposes. The number of evaluated municipalities is lower than the number of classified municipalities because in some municipalities the information about the number of voters is not available. 
Table 2: Descriptive statistics of voter turnout in $P B$ in the municipalities classified by the D21 voting method's criteria in 2019, $N=49$

\begin{tabular}{|c|c|c|c|c|}
\hline Voting methods & D21 & Modified D21 & Other & All \\
\hline Mean & 6.1 & 6.73 & 4.56 & 5.78 \\
\hline Stand dev & 4.9 & 5.6 & 4.03 & 4.81 \\
\hline Min & 1.38 & 0 & 0 & 0 \\
\hline Max & 18.44 & 17.61 & 11.81 & 18.44 \\
\hline $\mathrm{N}$ & 22 & 12 & 15 & 49 \\
\hline
\end{tabular}

Source: The authors

Table 2 shows the results of the analysis. Municipalities with the D21 method and the modified D21 method have higher average voter turnout in PB than municipalities with other methods. The difference is greater than 2 p.p. in the case of the modified D21 and other voting methods. When calculating the average voter turnout in PB for both the D21 method and its modification, it was $6.32 \%$. It shows that the results for the application of the D21 method in pure form are not significantly different compared to the modified D21 voting method. It seems that compliance with criterion 1 could be a sufficient condition to a higher participation rate.

Provision of balanced information required to identify the cases when the D21 method was changed. During the examination of individual cases of the PBs in the period 2014-2020, findings were identified that indicate a tendency that there are some possible shortcomings in the application of the D21 voting method regarding possible strategic voting and the incomprehensibility of the method. Jirásková (2018) points out that the D21 method used in simulated voting on projects in a small Czech municipality, is perceived by citizens as too complicated to be understood. However, they liked the possibility of casting of negative votes. Her testing was based on a paper ballot, and not on online voting, which could affect the complexity of the criteria and result in its complicated comprehensiveness. In Brno, the voting method was changed - minus votes were only used when there was an equal number of positive votes of the proposals, the core part of the D21 method was modified. During the evaluation meetings, proposers often criticized the minus votes as those enabling to vote strategically (e.g., Durdíková, 2018). Nevertheless, minus votes may not be the only reason for strategic voting; the visibility of the results for the whole period of voting 
is criticized as well (Hromádková, 2021). Havířov is another municipality where minus votes were cancelled in 2020 and the plurality voting method with one vote per voter was approved. There are some other municipalities that changed the D21 method to the modified D21 method - municipalities of Krnov and Klášterec nad Ohř́. Both municipalities started using the Neogenia online voting platform allowing the casting of more votes per a proposal. In other municipalities, the method was changed from plurality to more positive votes (e.g., Český Krumlov in 2020) or to the modified D21 method (municipality of Slaný after the first pilot project in 2017). The changes in the voting methods were not examined in detail, and the authors of the article plan continue researching and conducting surveys in specific municipalities where the voting method changed to investigate further information regarding the reasons. To sum up, the identified reasons for the change of the D21 method were strategic voting, difficult comprehension, and the change of an online platform for voting.

The analysis of voting method used in PB in the Czech Republic was performed on a sample of individual cases of municipalities in 2019. In the future, the authors intend to use a longer time series including a larger sample of municipalities. Additionally, it is possible to analyse the citizen participation in the group of municipalities using more positive votes without minus-votes (mainly cumulative voting). This verification was currently impossible because the sample used in this article contained only four municipalities with this kind of method. Subsequently, the next stage of the research might be the check of other variables with potential impact on the participation rate in the voting on PB proposals as the amount of the participatory budget, other conditions for participation (e.g., voting age or permanent address for voting eligibility, historical voter turnout in municipal elections, marketing expenses, size of the municipalities, number of proposals per citizen). The problem of strategic voting was often mentioned during the analysis of experience with the D21 method, which could be also a topic of further research. Next, consideration of the visibility of ongoing voting results for voters and participation in different intervals of the voting period could be analysed.

\section{CONCLUSION}

The results indicate that municipalities with the D21 method and the modified D21 method have higher voter turnout in PB than municipalities using another voting method. Certain modification of the D21 method (e.g., 
when only the first criterion of the definition is met) does not decrease the participation rate in $\mathrm{PB}$ on average. In the group of municipalities with the modified D21 method, the average voter turnout in PB is even slightly higher than in municipalities with the D21 method.

The analysis of the reasons in individual municipalities why the D21 method was changes identified three areas: strategic voting, problems with comprehension of the D21 method by voters, and the change of an online platform for voting to another one offering a different voting method.

The findings indicate that the choice of a proper voting rule may play an important role in in citizens' participation in PB. However, the use of the D21 method in accordance with all the definition criteria of this method does not guarantee a higher voter turnout in PB. Further research using a larger dataset over a longer period is needed to investigate impact of different kinds of modification of D21 (violation of each definition criterion) and to distinguish particular voting methods in the group of other voting methods.

The results may be relevant for municipalities considering a proper voting method for PB and identifying its benefits and drawbacks. The D21 method is used in different countries; therefore, the results could be also useful for municipalities abroad after abstraction of specific Czech conditions. Additionally, the analysis highlighted the influence of external organizations offering online platforms for voting.

\section{REFERENCES}

AGORA, CE. (2015). Výroční zpráva 2015. [online]. Available at: http:// agorace.cz/wp-content/uploads/2019/05/Vyrocni_zprava_2015.pdf [Accessed: 2021-08-27].

ARIELY, D. (2010). Predictably irrational: The hidden forces that shape our decisions. New York: Harper Perennial, 384 pp.

ARROW, K. (1951). Social choice and individual values. New York: Wiley, 99 pp.

ARROW, K. (1977). Current Developments in the Theory of Social Choice. In: Social Research. [online]. Vol. 44, No. 4, pp. 607-622. Available at: https:// www.jstor.org/stable/40971168 [Accessed: 2021-08-27].

ARROW, K. and MASKIN, E. (2012). Social Choice and Individual Values. New York: Yale University Press, $192 \mathrm{pp}$.

BARDOVIČ, J. and GAŠPARÍK, J. (2021). Enablers of Participatory Budgeting in Slovakia During the COVID-19 Pandemic. In: Scientific Papers of the University of Pardubice, Series D: Faculty of Economics and Administration. 
Vol. 29, No. 1, Article no. 1248. DOI: https://doi.org/10.46585/ sp29011248.

BECHTEL, M. M., HANGARTNER, D. and SCHMID, L. (2018). Compulsory Voting, Habit Formation, and Political Participation. In: The Review of Economics and Statistics. [online] Vol. 100, No. 3, pp. 467-476. DOI: https://doi.org/10.1162/rest_a_00701 [Accessed: 2021-08-27].

BHAGAT, S. and BRICKLEY, J. A. (1984). Cumulative Voting: The Value of Minority Shareholder Voting Rights. In: The Journal of Law and Economics. [online] Vol. 27, No. 2, pp. 339-365. DOI: https://doi. org/10.1086/467069 [Accessed: 2021-08-27].

BHATNAGAR, D., RATHORE, A., TORRES, M. and KANUNGO, P. (2003). Participatory budgeting in Brazil. In: World Bank Working Paper. [online] No. 51418, Empowerment Case Studies. Available at: https:// documents.worldbank.org/en/publication/documents-reports / documentdetail/600841468017069677/participatory-budgeting-inbrazil [Accessed: 2021-08-27].

BRAMS, S. and FISHBURN, P. (2007). Approval voting. New York: Springer Verlag, $200 \mathrm{pp}$.

BRAMS, S. and SANVER, M. (2009). Voting Systems that Combine Approval and Preference. In: Brams, S., Gehrlein, W. and Roberts, F. (ed.), The Mathematics of Preference, Choice, and Order. Studies in Choice and Welfare. Berlin, Heidelberg: Springer, pp. 215-237. DOI: https://doi. org/10.1007/978-3-540-79128-7_12.

BRAMS, S. J. and FISHBURN, P. C. (1978). Approval Voting. In: American Political Science Review. Vol. 72, No. 3, pp. 831-847. DOI: https://doi. org/10.2307/1955105 [Accessed: 2021-08-27].

CALABRESE, T., WILliAMS, D. and GUPTA, A. (2020). Does Participatory Budgeting Alter Public Spending? Evidence from New York City. In: Administration \& Society. [online] Vol. 52, No. 9, pp. 1382-1409. DOI: https://doi.org/10.1177/0095399720912548 [Accessed: 2021-08-27].

CARROL, C., CRUM, T., GAETE, C., HADDEN, M. and WEBER, R. (2016). Democratizing Tax Increment Financing Funds Through Participatory Budgeting. [online]. Available at: https://greatcities.uic.edu/wpcontent/uploads/2016/06/TIF-PB-Toolkit-June-2016.pdf [Accessed: 2021-08-27].

ČERNÝ, V. (2016). Metodika tvorby participativního rozpočtu pro města v ČR. [online]. Praha: Agora CE, 47 pp. Available at: https://www.participativnirozpocet.cz/wp-content/uploads/2017/05/Metodika_Participativni_ rozpocet_AGORA_CE.pdf [Accessed: 2021-08-27]. 
CONGLETON, R. (2001). Rational Ignorance, Rational Voter Expectations, and Public Policy: A Discrete Informational Foundation for Fiscal Illusion. In: Public Choice. [online] Vol. 107, pp. 35-64. DOI: https://doi. org/10.1023/A:1010337412291 [Accessed: 2021-08-27].

CZECH PIRATE PARTY. (2020). Participativní rozpočet. [online]. Available at: https://wiki.pirati.cz/fo/rozpocty/participativni/start [Accessed: 2021-08-27].

ĎURDÍKOVÁ, M. (2018). Participatory budgeting - theory and praxis. Diploma thesis. Masaryk University in Brno. Faculty of Economics and Administration.

DŽINIĆ, J., SVIDROŇOVÁ, M. and MARKOWSKA-BZDUCHA, E. (2016). Participatory Budgeting: A Comparative Study of Croatia, Poland, and Slovakia. In: NISPAcee Journal of Public Administration and Policy. [online]. Vol. 9, No. 1, pp. 31-56. DOI: https://doi.org/10.1515/nispa-2016-0002 [Accessed: 2021-08-27].

EUROPEAN PARLIAMENT. (2016). Participatory budgeting. An innovative approach. [online]. Briefing, January 2016. Available at: https://www. europarl.europa.eu/RegData/etudes/BRIE/2016/573894/EPRS_ BRI(2016)573894_EN.pdf [Accessed: 2021-08-27].

FÖLSCHER, A. (2007). Participatory Budgeting in Central and Eastern Europe. In: Shah, A. ed. Participatory Budgeting. Public Sector Governance and Accountability Series. Washington, D.C: World Bank, pp. 127-156.

GOODIN, R. and LIST, C. (2006). A Conditional Defense of Plurality Rule: Generalizing May's Theorem in a Restricted Informational Environment. In: American Journal of Political Science. [online]. Vol. 50, No. 4, pp. 940-949. DOI: https://doi.org/10.1111/j.1540-5907.2006.00225.x [Accessed: 2021-08-27].

GREEN-ARMYTAGE, J., TIDEMAN, T. and COSMAN, R. (2016). Statistical evaluation of voting rules. In: Social Choice and Welfare. [online]. Vol. 46, No. 1, pp. 183-212. D0I: https://doi.org/10.1007/s00355-015-0909-0 [Accessed: 2021-08-27].

GROFMAN, B. and FELD, S. (2004). If you like the alternative vote (a.k.a. the instant runoff), then you ought to know about the Coombs rule. In: Electoral Studies. [online]. Vol. 23, No.4, pp. 641-659. DOI: https://doi. org/10.1016/j.electstud.2003.08.001 [Accessed: 2021-08-27].

HAMAN, M. and ŠKOLNÍK, M. (2020). Socioeconomic or Political Variables? The Determinants of Voter Turnout in Czech Municipalities. In: Slovak Sociological Review. Vol. 52, No. 3, pp. 222-244. DOI: https://doi. org/10.31577/sociologia.2020.52.3.10. 
HROMÁDKOVÁ, A. (2021). Participativní rozpočty a hlasovací systém Demokracie 21. Diploma thesis. Mendel University in Brno. Faculty of Business and Administration.

JANEČEK, K. (2016). Democracy 2.1. 29 August 2016 [online]. Available at: https://uploads-ssl.webflow. com/5a61da42ae3f8f00019b46bd/5a893542d9716c0001a4a80d_d21. pdf [Accessed: 2021-08-27].

JIRÁSKOVÁ, M. (2018). Využití hlasovacího systému Demokracie 21. Diploma thesis. Mendel University in Brno. Faculty of Business and Administration. KAHNEMAN, D. and TVERSKY, A. (ed.) (2000). Choices, values, and frames. New York: Cambridge University Press, 860 pp. DOI: https://doi. org/10.1017/CBO9780511803475.

KUKUČKOVÁ, S. A POLÁCHOVÁ, M. (2021) The Impact of Different Voting Methods on Citizens' Participation in Participatory Budgeting. The case of the Czech Republic. In: Presentation on the Conference Economic Competitiveness and Sustainability. Brno: Mendel University in Brno, March 25th March, 2021.

KUKUČKOVÁ, S. and BAKOŠ, E. (2019). Does Participatory Budgeting Bolster Voter Turnout in Elections? The Case of the Czech Republic. In: NISPAcee Journal of Public Administration and Policy. [online]. Vol. 12, No. 2, pp. 109-129. DOI: https://doi.org/10.2478/nispa-2019-0016 [Accessed: 2021-08-27].

LASLIER, J. (2012). And the loser is... Plurality Voting. In: Felsenthal, D. and Machover, M. ed., Electoral Systems. Paradoxes, Assumptions, and Procedures. Berlin, Heidelberg: Springer, pp 327-351. DOI: https://doi. org/10.1007/978-3-642-20441-8_13.

LASLIER, J. and SANVER, M. (2010). Handbook on approval voting. Berlin, Heidelberg: Springer, pp. 480. DOI: https://doi.org/10.1007/978-3-64202839-7.

LERNER, J. and SECONDO, D. (2012). By the People, For the People: Participatory Budgeting from the Bottom Up in North America. In: Journal of Deliberative Democracy. [online]. Vol. 8, No. 2. DOI: https:// doi.org/10.16997/jdd.148 [Accessed: 2021-08-27].

MBIH, B., MOYOUWOU, I. and ZHAO, X. (2010). On the positive association of parliamentary social choice functions. In: Social Choice and Welfare. [online]. Vol. 35, No. 1, pp. 107-127. DOI: https://doi.org/10.1007/ s00355-009-0432-2 [Accessed: 2021-08-27]. 
MCLEAN, I. and MCMILLAN, A. (ed.). (2009). The concise Oxford dictionary of politics (3rd edn.). Oxford: Oxford University Press, 640 pp. DOI: https:// doi.org/10.1093/acref/9780199207800.001.0001.

MEIER, A., SCHMID, L. and STUTZER, A. (2019). Rain, emotions and voting for the status quo. In: European Economic Review. [online]. Vol. 119, pp. 434-451. DOI: https://doi.org/10.1016/j.euroecorev.2019.07.014 [Accessed: 2021-08-27].

MILLER, S., HILDRETH, R. and STEWART, L. (2019). The Modes of Participation: A Revised Frame for Identifying and Analyzing Participatory Budgeting Practices. In: Administration \& Society. [online]. Vol. 51, No. 8, pp. 1254-1281. DOI: https://doi.org/10.1177/0095399717718325 [Accessed: 2021-08-27].

MINÁRIK, P. (2020). Participatory Budgeting and Traditional Participation in Czech Municipalities. In: Slovak Journal of Political Sciences. Vol. 20, No. 1. pp. 29-47. DOI: https://doi.org/10.34135/sjps.200102.

OCHRANA, F. (2003). Veřejná volba a řízeníveřejných výdajů. Praha: Ekopress, $64 \mathrm{pp}$.

OFFICINA. (2021). Participatory Budgeting World Atlas. [online]. Available at: https://www.pbatlas.net/europe.html.

OLEJNICZAK, J. and BEDNARSKA-OLEJNICZAK, D. (2018). Participatory Budgeting in Poland in 2013 - 2018: Six Years of Experiences and Directions of Changes. In: Dias, N. ed.. Hope for Democracy: 30 Years of Participatory Budgeting. [online]. Epopeia Records. pp. 337 - 354. Available at: https://www.oficina.org.pt/hopefordemocracy.html [Accessed: 2021-07-27].

PAPE, M. and LERNER, J. (2016). Budgeting for Equity: How Can Participatory Budgeting Advance Equity in the United States? In: Journal of Deliberative Democracy. [online]. Vol. 12, No. 2, Article 9. DOI: https:// doi.org/10.16997/jdd.261 [Accessed: 2021-08-27].

POUNDSTONE, W (2008) Gaming the Vote: Why Elections Aren't Fair (and What We Can Do About It). New York City: Hill and Wang, 352 pp.

REGENWETTER, M. (ed.). (2006). Behavioral social choice: Probabilistic models, statistical inference, and applications. New York: Cambridge University Press. 258 pp.

REGENWETTER, M., GROFMAN, B., POPOVA, A., MESSNER, W., DAVISSTOBER, C. and CAVAGNARO, D. (2009). Behavioural social choice: A status report. In: Philosophical Transactions of the Royal Society B: Biological Sciences. Vol. 364, No. 1518, pp. 833-843. DOI: https://doi. org/10.1098/rstb.2008.0259. 
SEDMIHRADSKÁ, L., KUKUČKOVÁ, S. and BAKOŠ, E. (2022, In Press). ProjectOriented Participatory Budgeting in the Czech Republic. In: De Vries, M. S., Nemec, J. and Špaček, D. eds.: International Trends in Participatory Budgeting: Between Trivial Pursuits and Best Practices. Cham: Palgrave Macmillan, pp. 131-147. DOI: https://doi.org/10.1007/978-3-03079930-4_7.

SHAH, A. (ed.). (2007). Participatory budgeting. Public Sector Governance and Accountability. [online]. Washington, DC: World Bank. DOI: https:// doi.org/10.1596/978-0-8213-6923-4 [Accessed: 2021-08-27].

SINTOMER, Y., HERZBERG, C. and RÖCKE, A. (2008). Participatory Budgeting in Europe: Potentials and Challenges: Participatory budgeting in Europe. In: International Journal of Urban and Regional Research. [online]. Vol. 32, No. 1, pp. 164-178. DOI: https://doi.org/10.1111/j.14682427.2008.00777.x [Accessed: 2021-08-27].

TABARROK, A. (2015). Arrow's Impossibility Theorem. [online]. Presentation at Department of Economics, George Mason University. March 4, 2015. Available at: https://mason.gmu.edu/ atabarro/arrowstheorem.pdf [Accessed: 2021-08-27].

THALER, R. and SUNSTEIN, C. (2009). Nudge: Improving decisions about health, wealth, and happiness. London: Penguin Books, 320 pp.

WAMPLER, B. (2012). Participatory Budgeting: Core Principles and Key Impacts. In: Journal of Public Deliberation. [online]. Vol. 8, No. 2, Article no. 12. DOI: https://doi.org/10.16997/jdd.138 [Accessed: 2021-08-27]. WODAK, D. (2019). The Expressive Case against Plurality Rule. In: Journal of Political Philosophy. [online]. Vol. 27, No. 3, pp. 363-387. DOI: https:// doi.org/10.1111/jopp.12188 [Accessed: 2021-08-27].

YOUNG, H. (1988). Condorcet's Theory of Voting. In: American Political Science Review. [online]. Vol. 82, No. 4, pp. 1231-1244. DOI: https://doi. org/10.2307/1961757 [Accessed: 2021-08-27].

ZEPIC, R., DAPP, M. and KRCMAR, H. (2017). E-Partizipation und keiner macht mit: Das Geheimnis geringer Beteiligungsquoten deutscher Bürgerhaushalte. In: HMD Praxis der Wirtschaftsinformatik [online]. Vol. 54, No. 4, pp. 488-501. DOI: https://doi.org/10.1365/s40702-0170328-z [Accessed: 2021-08-27]. 